\title{
Toronto's science jewel
}

\author{
A small Canadian institute is producing a disproportionate number of \\ highly cited biology papers. Trisha Gura visited the Amgen Institute, to \\ find out what its members are doing right.
}

E ach spring, the newsletter Science Watch unveils a list that must have some scientists green with envy. Compiled by ISI, formerly the Institute for Scientific Information in Philadelphia, the list documents those researchers who have produced the most 'hot' papers over the preceding two years - those judged by a bespoke computer algorithm to be cited markedly more in the scientific literature than comparable papers.

Thirteen individuals who produced five or more such papers in 1999-2000 headed this year's roll of honour. Three of them are based at the Amgen Institute in Toronto. If citation analysis is a valid measure of scientific quality, then this small research centre, which specializes in disrupting mouse genes, must be one of the most distilled concentrations of excellence on the planet. It has only six faculty members, and just 50 scientists in total, including graduate students. So what explains its success?

In part, the answer lies in annual funding of some $\$ 8$ million from Amgen, the biotech giant of Thousand Oaks, California. But researchers familiar with the institute say that another defining factor is the personality and scientific style of its director, Tak Wah Mak.

\section{Seeds of success}

The story began in the early 1980s, when Mak was working at the Ontario Cancer Institute (OCI) in Toronto. Canadian funding for biomedical research was far from generous, and Mak had to scrimp and save to pursue his work on leukaemias triggered by retroviruses. In an attempt to garner more funding, he began to work on the immune system's $\mathrm{T}$ cells, which play an major role in destroying virus-infected cells.

The big break came in 1984, when researchers led by Mak became one of the two teams that won the race to clone the gene for the main receptor that enables T cells to lock onto their targets ${ }^{1}$. The paper caught the eye of officials at Amgen, and the soft-spoken but shrewd Mak used the access this gave him to the company's executives to discuss a risky academic-industrial partnership.

Mak's idea was to create a research institute that would advance fundamental research while giving Amgen information about potential drug targets - the company would own any patents arising from the work, even if it was supported in part by outside grants. 'm not looking for
people who can dot 'i's and cross 't's. I need people who will hit grand slams.

Eventually, Amgen bought into the idea, and in 1993 created the Amgen Institute across two floors of renovated labs in the building that houses the OCI. As well as providing core lab running costs, Amgen pays the salaries of the six faculty members, plus two postdocs and a technician for each.

Unusually for an industry-funded facility, Mak was given almost complete freedom to explore the science that he deemed most interesting. "Tak convinced Amgen to support him in this work, more or less without direction from the company," says Nobel laureate David Baltimore, president of the California Institute of Technology in Pasadena, and one of Amgen's board of directors.

The institute's work revolves around selectively knocking out individual genes in mice to study T-cell development and other biological problems. Close observers say that Mak's uncanny ability to pick the right genetic targets for knockout experiments is the key to his success. "Tak is one of the best judges of science that I have ever seen," says Christopher Paige, vice-president of research at the OCI.

The promotion of young scientific talent is a top priority for Mak, and students at the University of Toronto flock to his lab. Graduate student Megan Cully relates what happened after she and two postdocs found a series of new links between a tumour-suppressor gene called PTEN and the betterknown gene $p 53$. "Tak immediately called some of the top p53 people in the world," she says. Within weeks, the experts showed up at the institute, and everyone discussed the new data.

\section{Knockout punch}

From his initial focus on T cells, Mak has branched out into studying the genes that control cell division and the 'programmed' cell death known as apoptosis. For example, his group has disrupted mouse genes including Chk2, which codes for an enzyme that checks for DNA damage during cell division and helps to trigger apoptosis in the event of problems ${ }^{2}$. In another of Mak's hot papers, his team showed that knocking out genes that inhibit an important pathway involved in innate immunity - the initial inflammatory response to an infection - causes mouse embryos to die of liver degeneration, as a result of apoptosis ${ }^{3}$.

Mak believes the institute's success has as much to do with its

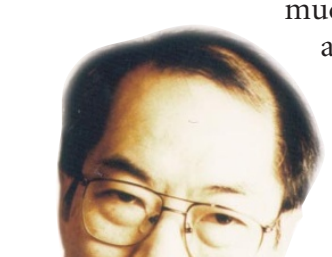
approach to science as its funding from Amgen. "I urge people in the lab to do the experiments that will move the field," he says. "I'm not looking Free thinker: Tak Wah Mak, founder of the Amgen Institute. 
for people who can dot 'i's and cross 't's. I need people who will hit grand slams."

Thanks to this policy, Mak now has some serious competition as the institute's star performer. On the same floor as his lab is the workplace of Josef Penninger, an Austrian immunologist who seems to cultivate the image of an eccentric scientist. With his unruly dark hair, the gangly and engaging Penninger has become something of a celebrity, featuring on Canadian television and in magazine articles.

Three of Mak's five hot papers in 1999-2000 were co-authored by Penninger - and on two of them, the Austrian was the corresponding author. One of the joint papers showed that a protein called OPGL is involved both in the development of immune cells and in bone loss ${ }^{4}$. The other revealed the diverse roles of the protein TRAF-6, involved in inflammation and the maturation of cells called osteoclasts that help to repair and remodel bone ${ }^{5}$. In the third joint production, Mak and Penninger found that a protein involved in processing lipids regulates the activation of T cells ${ }^{6}$.

Penninger also scored two hot papers without his boss. One identified a novel apoptosis-inducing factor and laid out its detailed workings in a previously unknown pathway of cell death ${ }^{7}$. The other linked OPGL with arthritis". "Josef is an exceptionally bright young guy," says Alan Bernstein, president of the Canadian Institutes for Health Research and director of the Samuel Lunenfeld Research Institute, also in Toronto. "Heknows how to motivate his team and have fun."

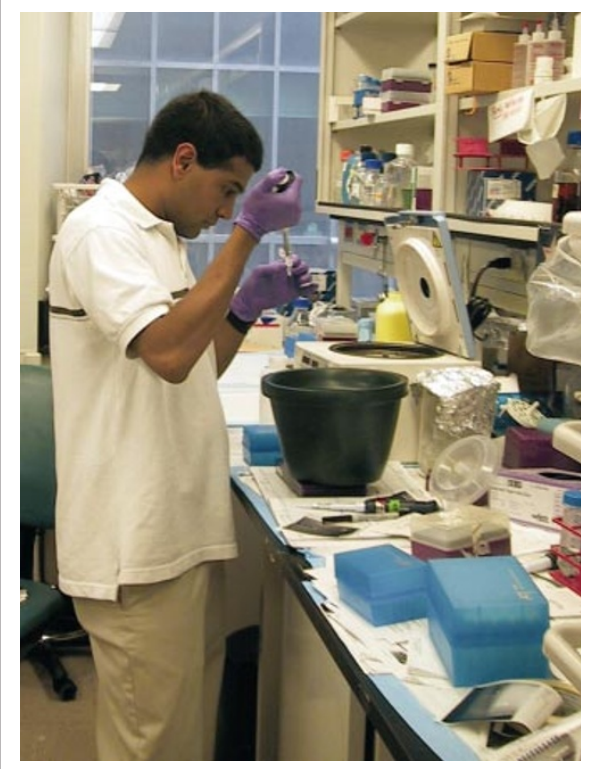

\footnotetext{
he promotion of young scientific talent is a top priority at the institute.
}

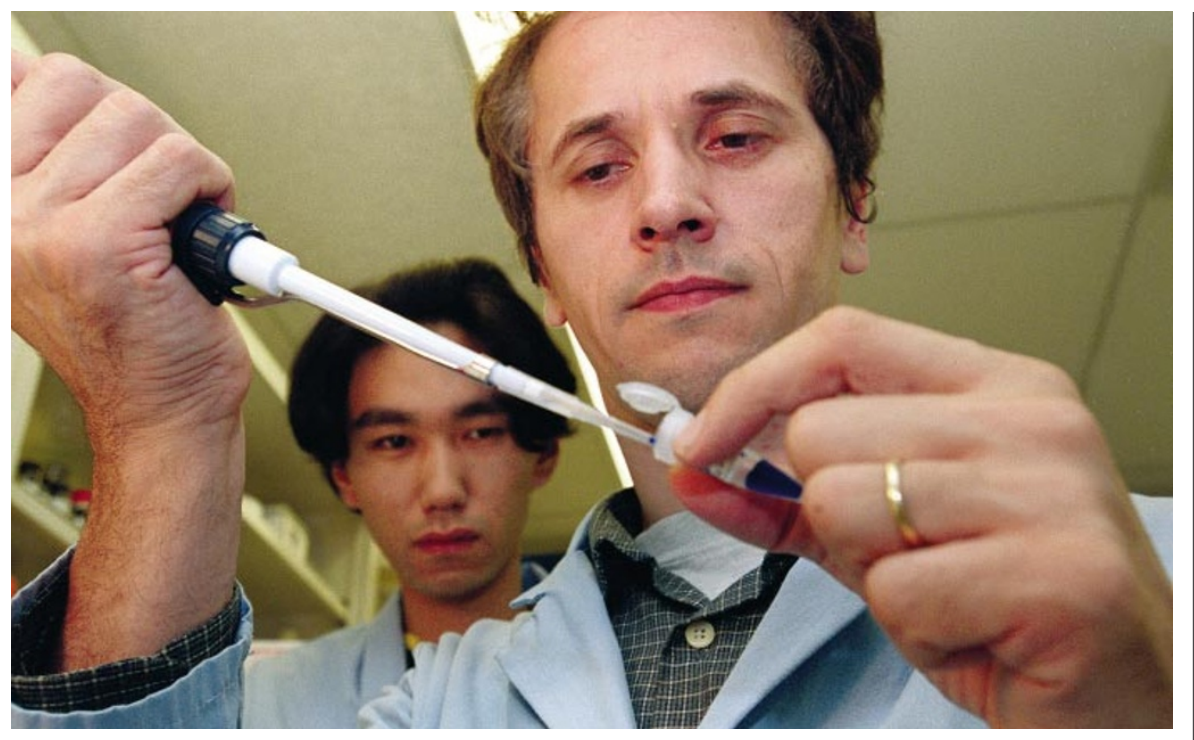

Celebrated performer: Josef Penninger aims for projects that will have 'impact on people's lives'.

Penninger's success did not come overnight. He joined Mak's lab as a postdoc in 1990, and was recruited to the Amgen Institute's faculty a year after its inception. But initially, he remained in Mak's long shadow. If he continued to work on T-cell development, Penninger knew he would always be seen as a Mak acolyte. But Canadian agencies were unwilling to fund his attempts to expand into other areas. Jim Woodgett, a molecular biologist at the OCI, blames Canada's tendency towards egalitarianism: given Amgen's bankrolling of the institute, he suspects that reviewers were happier backing projects elsewhere.

\section{Carving a niche}

But the tide turned for Penninger in 1997, with the publication in Nature of a paper $^{9}$ describing the knockout of a gene called Sek-1, which is involved in an important stress signalling pathway. After that success, funding bodies could no longer ignore Penninger's claims, and he began to investigate bone loss and heart disease, knocking out a variety of genes he thought might play important roles.

This focus on prominent diseases was grounded in practical considerations. "I am always looking for projects that will have some impact on people's lives," he says. His projects have also had a major scientific impact. Today, a line of 14 empty champagne bottles sits perched on Penninger's windowledge. Each carries a reference to one of his papers in Nature or Science.

The final member of the Amgen Institute's triumvirate of citation stars is Andrew Wakeham - who isn't even a faculty member. Creating knockout mice involves mutating a gene and then injecting it into scores of pre-implantation embryos in the hope that, in some cases, a phenomenon known as homologous recombination will cause it to displace the normal version. Wakeham is a technician who is highly skilled at injecting embryos. Mak hired him as a research associate and he is named as a co-author on many papers emanating from the institute. "The standing joke is that Drew will beat us all," says Penninger.

But the institute can be a harshly competitive place to work. After it had been operating for three years, for instance, Mak called in an outside panel — chaired by Baltimore to scrutinize its output. As a result, three investigators' contracts were not renewed. The move attracted some criticism, particularly after two of the outgoing researchers were replaced with postdocs from Mak's lab.

In addition to its scientific output, Mak says that the institute has provided its parent company with three drug leads - although none has yet been publicly declared. And its work on OPGL is helping to underpin Amgen's plans to develop the protein as a treatment for osteoporosis and arthritis.

But looking to the future, Mak admits to worries. Amgen's chief executive officer, Gordon Binder, and Larry Souza, the company's head of research, both retired last year. Although the institute's funding was renewed until 2008 before Souza's departure, incoming research chief Roger Perlmutter has yet to make his plans for the institute clear - and Amgen did not respond to requests to be interviewed for this article. But despite Mak's doubts about the future, other researchers would happily swap places with him. "I'd take that risk any day," says Woodgett.

Trisha Gura is a science writer based in Cleveland, Ohio.

1. Yanagi, Y. et al. Nature 308, 145-149 (1984).

2. Hirao, A. et al. Science 287, 1824-1827 (2000).

3. Rudolph, D. et al. Genes Dev. 14, 854-862 (2000).

4. Kong, Y.-Y. et al. Nature 397, 315-323 (1999).

5. Lomaga, M. A. et al. Genes Dev. 13, 1015-1024 (1999).

6. Sasaki, T. et al. Science 287, 1040-1046 (2000).

7. Susin, S. A. et al. Nature 397, 441-446 (1999).

8. Kong, Y.-Y. et al. Nature 402, 304-309 (1999).

9. Nishina, H. et al. Nature 385, 350-353 (1997). 